\title{
Microdetermination of calcium and magnesium in biological materials
}

\author{
C. H. BOWDEN ${ }^{1}$ A ND VALERIE J. PATSTON \\ From the Department of Chemical Pathology, Westminster Medical School, London
}

SYNOPSIS The use of the dye calcon (1-(2 hydroxy-1-naphthylazo)-2-naphthol-4 sulphonic acid) for the estimation of calcium using E.D.T.A. and a commercial photoelectric titrimeter is described. The interfering effects of magnesium and phosphate have been overcome. The method has been extended to estimations on biological materials.

Results on 55 sera show that the E.D.T.A./calcon method gave slightly lower results $(-0.15 \mathrm{mg}$./ $100 \mathrm{ml} . \pm 0.029)$ than the oxalate precipitation method.

Magnesium may also be estimated by incorporating the use of Eriochrome black $T$.

The dye calcon (1 (2 hydroxy-1-naphthylazo)-2naphthol-4 sulphonic acid), which was investigated by Hildebrand and Reilley (1957) and adapted for use in serum calcium estimations by Golby, Hildebrand, and Reilley (1957), appears to be a real improvement on murexide, in both stability and colour change. Aqueous solutions of calcon produce a blue colour between $p \mathrm{H}$ values of $7 \cdot 4$ and $13 \cdot 5$. Below $p \mathrm{H} 7.4$ and above $p \mathrm{H} 13.5$ the indicator is red. At approximately $p \mathrm{H} 13$, where magnesium is quantitatively precipitated as the hydroxide, only calcium ions react with calcon to form a red coloured complex. Thus under these conditions the calcium-calcon complex can to titrated with E.D.T.A. (ethylenediamine-tetra acetic acid) from a red to a pure blue end-point without interference from magnesium.

In our experience, however, the visual end-point described by Golby et al. (1957) is not sufficiently sharp to give highly accurate results. Also as sera vary greatly in tint the colour of the end-point will vary accordingly. We therefore made use of a commercial titrator and galvanometer, which gave a far more accurate determination of the end-point. A single calcium estimation using this apparatus takes less than three minutes. The method has been adapted satisfactorily for calcium estimations in serum, urine, food, and faeces.

\section{EXPERIMENTAL}

APPARATus The EEL titrator (Evans Electroselenium) used in conjunction with an EEL Unigalvo type 20

'Present address: Royal Air Force Institute of Pathology and Tropical Medicine, Halton, Aylesbury, Bucks.

Received for publication 29 September 1962. galvanometer was used throughout the work described. The instrument consists basically of a colorimeter with a built-in magnetic stirrer. Flanged beakers ( $4 \mathrm{ml}$. capacity) are supplied which are correctly located in the light beam which is focused at the centre of the solution in the beaker. Various Ilford filters can be selected for use as necessary.

As no error in the end-point is caused by moderate dilution of the sample it was unnecessary to use a micrometer syringe when titrating with E.D.T.A. Therefore a $2 \mathrm{ml}$. Excello automatic micro burette ${ }^{2}$ graduated in $0.01 \mathrm{ml}$. divisions was used. The burette was modified by fitting it with a diaphragm plastic tap ${ }^{3}$ which permitted accurate $0.01 \mathrm{ml}$. additions. The burette jet was either drawn out finely or the tap fitted with a hypodermic needle.

OPTICAL CONDITIONS FOR TITRATION The exact position of the absorption peaks, the molar extinction, and the stability of the colour of the free calcon and of the calcium complex are all dependent on $p \mathrm{H}$. Above $p \mathrm{H} 13$ the stability and the extinction of the free calcon is greatly reduced (Hildebrand and Reilley, 1957). However, the advantage of avoiding both the necessity of neutralizing acid extracts before titration and magnesium interference by using high $p \mathrm{H}$ levels outweighs the disadvantages of decreased dye stability and reduced optical density values. Under the working conditions described below the free dye had a loss of optical density of $1 \%$ at five minutes at wavelength 490 rising to $20 \%$ at 20 minutes. Under the same conditions the calcium-calcon complex showed no significant change.

DETERMINATION OF THE END-POINT FROM TITRATION CURVES Figure 1 shows the titration curve of a standard W. G. Flaig \& Sons Ltd., 39, Waterloo Road, London, N.W.2.

${ }^{3}$ Townson and Mercer, Croydon, Surrey. 


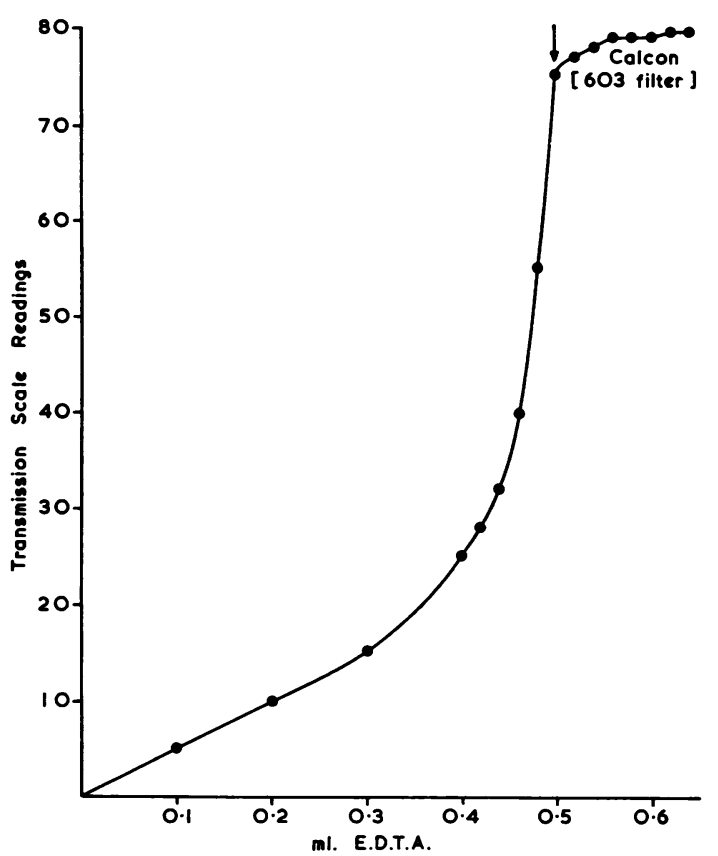

FIG. 1. Titration curve for dilute calcium standard with E.D.T.A. using calcon as indicator.

calcium solution using an Ilford 603 filter and galvanometer transmission scale.

The end-point can be determined without drawing a titration curve by noting the greatest difference in transmission scale deflection for each $0.01 \mathrm{ml}$. of E.D.T.A. added. This corresponds to the maximum rate of deflection and the end-point is taken as the second of the two readings showing a maximum difference.

REAGENTS The following were required:-

Stock calcium solution $(0 \cdot 01251 \mathrm{M}$ or $50 \mathrm{mg}$. $\mathrm{Ca} / 100$ ml.) $1.251 \mathrm{~g}$., $\mathrm{CaCO}_{3}$ anhydrous $\mathrm{AR}$ (dried at $120^{\circ} \mathrm{C}$. and stored in a vacuum desiccator) is added to $150 \mathrm{ml}$. distilled water. After the addition of $25 \mathrm{ml}$. NHCL the solution is made up to 1 litre.

Dilute calcium working solution $(5 \mathrm{mg}$. Ca/100 ml.) Dilute the stock calcium solution 1:10 with distilled water.

Diamino-ethane-tetra acetic acid solution (E.D.T.A.) $(0.0025 \mathrm{M})$ Diamino-ethane-tetra acetic acid disodium salt, 0.9306 g., is dissolved in 1 litre of distilled water.

Stock calcon indicator Calcon, $450 \mathrm{mg}$, is dissolved in $10 \mathrm{ml}$. methanol AR.

Dilute calcon indicator Dilute stock solution $1: 25$ with methanol.

$2 N$ Sodium hydroxide All aqueous reagents are prepared using ion exchange water and stored in polythene bottles.

'J. T. Baker Chemical Co., U.S.A., obtainable from Omni (G.B.) Ltd., 35 Dover Street, London, W.1.
STANDARDIZATION OF E.D.T.A. SOLUTION Into the $4 \mathrm{ml}$. beaker pipette $1 \mathrm{ml}$. dilute calcium standard, and add $0.5 \mathrm{ml} .2 \mathrm{~N} \mathrm{NaOH}$ and $0.2 \mathrm{ml}$. dilute calcon indicator. With medium to maximum sensitivity setting and using the Ilford 603 filter, titrate until the end-point begins to change colour, and re-set the galvanometer zero control to obtain a zero reading. Add the E.D.T.A. in $0.02 \mathrm{ml}$. or $0.01 \mathrm{ml}$. quantities. The end-point is determined as above. This can be interpolated to within 0.01 or $0.005 \mathrm{ml}$. if $0.02 \mathrm{ml}$. or $0.01 \mathrm{ml}$. additions are used.

The titration reading should be $0.5 \mathrm{ml}$. of E.D.T.A. for $1 \mathrm{ml}$. of the dilute calcium standard after allowance for the blank reading. The E.D.T.A. can be adjusted or a titration factor applied.

DETERMINATION OF REAGENT BLANK Using analytical reagents the blank values are extremely low (approximately $0.005 \mathrm{ml}$.) and to evaluate them it is necessary to follow Wilkinson's (1957) method of titrating a standard solution to past the end-point, adding more standard to the beaker and re-titrating.

Titration 2 - titration $1=$ true reading of standard

Titration 1 - true standard reading = blank reading

TITRATION OF SERUM Into the $4 \mathrm{ml}$. beaker pipette $0.5 \mathrm{ml}$. serum and $0.5 \mathrm{ml}$. $2 \mathrm{~N} \mathrm{NaOH}$ and $0.2 \mathrm{ml}$. dilute calcon indicator and approximately $0.5 \mathrm{ml}$. of distilled water to adjust the level of the solution above the light path. Titrate as above using increased or maximum sensitivity for lipaemic or coloured sera.

When necessary satisfactory results can be obtained on $0.2 \mathrm{ml}$. of serum using titration additions of $0.01 \mathrm{ml}$. E.D.T.A.

Calculation Using $0.5 \mathrm{ml}$. serum calcium $(\mathrm{mg} . / 100 \mathrm{ml}$.) $=$ titration reading $\times 10 \times 2$.

STORAGE OF CALCON SOLUTION Satisfactory results were obtained with stock calcon and dilute calcon solution stored at room temperature up to a period of eight weeks and three weeks respectively. Storage in a deep freeze cabinet or refrigerator considerably increased the period of stability.

OPTIMUM CALCON CONCENTRATION It was found that the optimum calcon concentration was that which gives a free dye extinction of about 0.2 to 0.3 at $490 \mathrm{~m} \mu$. Using the indicator specified above this corresponds to $0.2 \mathrm{ml}$. dilute indicator as in the method described. The indicators obtained from British Drug Houses and Hopkins and Williams had to be made up to double the concentration indicated. These indicators appear to give an inferior visual end-point but can be used with the titrimeter.

\section{RESULTS}

RECOVERY OF CALCIUM ADDED TO SERUM Varying amounts of calcium were added to three normal sera by adding stock calcium standard to the titration beaker after pipetting the serum. Table $I$ indicates 
TABLE I

\begin{tabular}{|c|c|c|c|c|}
\hline \multicolumn{5}{|c|}{ RECOVERIES OF CALCIUM ADDED TO 11 SERA } \\
\hline & $\begin{array}{l}\text { Calcium Added } \\
(\mathrm{mg} . / 100 \mathrm{ml} .)\end{array}$ & $\begin{array}{l}\text { Total Calcium } \\
\text { Found } \\
(\mathrm{mg} . / 100 \mathrm{ml} .)\end{array}$ & $\begin{array}{l}\text { Calcium Recovered } \\
(\mathrm{mg} . / 100 \mathrm{ml} .)\end{array}$ & $\begin{array}{l}\text { \% Calcium } \\
\text { Recovery }\end{array}$ \\
\hline Normal 1 & $\begin{array}{r}- \\
5 \cdot 4 \\
10 \cdot 8 \\
20 \cdot 0\end{array}$ & $\begin{array}{r}8 \cdot 6 \\
14 \cdot 0 \\
19 \cdot 4 \\
28 \cdot 8\end{array}$ & $\begin{array}{r}- \\
5 \cdot 4 \\
10 \cdot 8 \\
20 \cdot 2\end{array}$ & $\begin{array}{l}-\overline{100} \\
100 \\
101\end{array}$ \\
\hline Normal 2 & $\begin{array}{l}- \\
0 \cdot 6 \\
8 \cdot 8\end{array}$ & $\begin{array}{l}10 \cdot 2 \\
10 \cdot 8 \\
19 \cdot 2\end{array}$ & $\begin{array}{l}\overline{0.6} \\
9 \cdot 0\end{array}$ & $\begin{array}{l}\overline{100} \\
102\end{array}$ \\
\hline Normal 3 & $\begin{array}{r}- \\
0 \cdot 4 \\
6 \cdot 2 \\
13 \cdot 0\end{array}$ & $\begin{array}{r}9 \cdot 8 \\
10 \cdot 2 \\
15 \cdot 8 \\
22.6\end{array}$ & $\begin{array}{r}- \\
0.4 \\
6 \cdot 0 \\
12 \cdot 8\end{array}$ & $\begin{array}{c}\overline{100} \\
97 \\
98.5\end{array}$ \\
\hline Haemolysed serum & $\begin{array}{l}- \\
2.0 \\
5 \cdot 2 \\
7 \cdot 8\end{array}$ & $\begin{array}{l}10 \cdot 0 \\
12.0 \\
15 \cdot 2 \\
17 \cdot 8\end{array}$ & $\begin{array}{l}- \\
2 \cdot 0 \\
5 \cdot 2 \\
7 \cdot 8\end{array}$ & $\begin{array}{r}-\overline{100} \\
100 \\
100\end{array}$ \\
\hline Grossly haemolysed serum & $\overline{5} \cdot 0$ & $\begin{array}{r}9 \cdot 0 \\
14 \cdot 2\end{array}$ & $-5 \cdot 2$ & $\overline{104}$ \\
\hline L ipaemic serum & $\begin{array}{r}- \\
1 \cdot 0 \\
5 \cdot 2 \\
10 \cdot 4\end{array}$ & $\begin{array}{l}11 \cdot 2 \\
12 \cdot 2 \\
16 \cdot 4 \\
21 \cdot 2\end{array}$ & $\begin{array}{r}- \\
1 \cdot 0 \\
5 \cdot 2 \\
10 \cdot 0\end{array}$ & $\begin{array}{r}-\overline{100} \\
100 \\
96\end{array}$ \\
\hline Grossly lipaemic serum & $\begin{array}{r}- \\
5 \cdot 0 \\
10 \cdot 4\end{array}$ & $\begin{array}{l}10 \cdot 2 \\
15 \cdot 4 \\
20 \cdot 6\end{array}$ & $\begin{array}{r}- \\
5 \cdot 2 \\
10 \cdot 4\end{array}$ & $\begin{array}{r}\overline{104} \\
100\end{array}$ \\
\hline Jaundiced serum (total bilirubin $=3.4 \mathrm{mg} .100 \mathrm{ml}$.) & $\begin{array}{l}- \\
2 \cdot 2 \\
7 \cdot 2\end{array}$ & $\begin{array}{r}8 \cdot 4 \\
10 \cdot 6 \\
15 \cdot 8\end{array}$ & $\begin{array}{l}\overline{2} \cdot 2 \\
7 \cdot 4\end{array}$ & $\begin{array}{l}100 \\
102 \cdot 8\end{array}$ \\
\hline Jaundiced serum (total bilirubin $=4.0 \mathrm{mg} . / 100 \mathrm{ml}$.) & $\begin{array}{l}\overline{0} \cdot 4 \\
9 \cdot 2\end{array}$ & $\begin{array}{r}9 \cdot 4 \\
9 \cdot 8 \\
18 \cdot 8\end{array}$ & $\begin{array}{l}\overline{0} \cdot 4 \\
9 \cdot 4\end{array}$ & $\begin{array}{l}\overline{100} \\
102\end{array}$ \\
\hline $\begin{array}{l}\text { Jaundiced serum (total bilirubin }=6.0 \mathrm{mg} . / 100 \mathrm{ml} \text {.) } \\
\text { also lipaemic }\end{array}$ & $\overline{5 \cdot 6}$ & $\begin{array}{r}8 \cdot 8 \\
14 \cdot 6\end{array}$ & $\overrightarrow{5 \cdot 8}$ & $\overline{103 \cdot 5}$ \\
\hline Jaundiced serum (total bilirubin $=18.4 \mathrm{mg} . / 100 \mathrm{ml}$.) & $\begin{array}{l}\overline{2} \cdot 2 \\
8 \cdot 4\end{array}$ & $\begin{array}{r}9 \cdot 6 \\
11 \cdot 6 \\
18 \cdot 0\end{array}$ & $\begin{array}{l}- \\
2 \cdot 0 \\
8 \cdot 4\end{array}$ & $\begin{array}{r}\overline{91} \\
100\end{array}$ \\
\hline
\end{tabular}

the satisfactory recoveries obtained. Similar recovery experiments were carried out on lipaemic, haemolysed, and icteric sera. In such cases visual colour change varies according to the colour of the original serum, and, in most cases, the galvanometer sensitivity setting should be increased to give satisfactory deflection readings. In cases of gross lipaemia the maximum sensitivity setting should be used. Table I indicates satisfactory recoveries in all cases investigated.

EFFECT OF MAGNESIUM Magnesium is precipitated at the $p \mathrm{H}$ used in the method, and it was considered possible that calcium might be co-precipitated or that the precipitate formed might interfere with the end-point. Varying amounts of stock magnesium standard were therefore added to the titration beaker after pipetting the serum or calcium solution.
Table II shows satisfactory calcium recoveries even at levels of $100 \mathrm{mg} . \%$ magnesium. However, the heavy flocculant precipitates at high magnesium concentrations above $20 \mathrm{mg}$. \% cause jumpy galvano- $\frac{D}{0}$ meter readings due to interference with the light beam. Such values, however, are unlikely to be found $N$ in pathological sera.

EFFECT OF PHOSPHATE It was expected that high levels of phosphate would interfere with the endpoint. Phosphate was therefore added to serum in the titration beaker using varying amounts of a solution of potassium dihydrogen phosphate equivalent to $50 \mathrm{mg}$. $\mathrm{P} / 100 \mathrm{ml}$. Table III shows the results obtained. The interference with the end-point is $\underset{\mathbb{D}}{\mathrm{D}}$ characterized by a premature appearance of the blue $\stackrel{?}{\mathbb{D}}$ end-point which then slowly reverts back to red. By 0 slow titration this effect can be minimized up to a? 
TABLE II

EFFECT OF ADDED MAGNESIUM ON CALCIUM ESTIMATION

\begin{tabular}{|c|c|c|}
\hline & $\begin{array}{l}\text { Magnesium Added } \\
\text { (mg./100 ml.) }\end{array}$ & $\begin{array}{l}\text { Calcium } \\
\text { (mg./100 }\end{array}$ \\
\hline Standard calcium solution & $\begin{array}{r}- \\
5.0 \\
10.0 \\
20.0 \\
50.0 \\
100.0\end{array}$ & $\begin{array}{r}10.0 \\
10.0 \\
10.0 \\
10.0 \\
9.8 \\
9.8\end{array}$ \\
\hline Serum I & $\begin{array}{r}- \\
5.0 \\
10.0 \\
20.0\end{array}$ & $\begin{array}{l}9 \cdot 4 \\
9 \cdot 4 \\
9 \cdot 4 \\
9 \cdot 4\end{array}$ \\
\hline Serum II & $\begin{array}{r}\overline{10 \cdot 0} \\
100 \cdot 0\end{array}$ & $\begin{array}{l}10.0 \\
10.0 \\
10.2\end{array}$ \\
\hline Serum III & $\begin{array}{r}- \\
50.0 \\
50.0\end{array}$ & $\begin{array}{l}10.4 \\
10.4 \\
10.6\end{array}$ \\
\hline Serum IV & $\begin{array}{r}- \\
5 \cdot 0 \\
10 \cdot 0 \\
20 \cdot 0\end{array}$ & $\begin{array}{l}10.2 \\
10.2 \\
10.4 \\
10.2\end{array}$ \\
\hline
\end{tabular}

phosphate level of $10 \mathrm{mg} . / 100 \mathrm{ml}$. Bett and Fraser (1959) noted that the interference was directly related to the concentration of phosphate in the titration solution and not to the ratio of the calcium and phosphate ions. Thus by further dilution of the titration solution with $1 \mathrm{ml}$. or $2 \mathrm{ml}$. of water the level at which phosphate interferes can be raised to 15 to $20 \mathrm{mg}$./100 ml. If this dilution is carried out a corresponding increase in the amount of calcon dye should be made. Since $2 \mathrm{~N} \mathrm{NaOH}$ is used to give the high $p \mathrm{H}$ for the titration, the dilution can be made without going below $p \mathrm{H} 13$. However, if many estimations are to be carried out on materials with a high phosphate content it is desirable to use a morpholine nitrate-nitric acid precipitation technique discussed below.

EFFECT OF ANTICOAGULANTS Calcium concentrations were estimated on sera obtained from normally clotted blood and on plasma samples obtained by use of E.D.T.A. oxalate, heparin, and liquid citrate as anticoagulants.

The E.D.T.A. plasma gave zero values. Oxalated plasma appeared to retain a very small amount of calcium which approximated to $0.4 \mathrm{~m} . \mathrm{g} / 100 \mathrm{ml}$. in all samples. Using liquid citrate as anticoagulant and allowing for dilution, calcium results were obtained which were very closely comparable with those on sera (mean difference $=+0.10 \mathrm{mg} . / 100 \mathrm{ml}$. \pm 0.009). Heparinized plasma also gave results which compared very closely with those found in sera from the same subjects (mean difference $+0.02 \mathrm{mg} . / 100$ ml. \pm 0.003 ).

\section{OXALATE PRECIPITATION AND E.D.T.A./CALCON ESTIMATION OF CALCIUM COMPARED}

Calcium estimations by the Clark and Collip (1925) oxalate precipitation method (modified by Wheatley, 1944) and the calcon method described were made on 55 miscellaneous normal and pathological sera with the following results. The oxalate precipitation method gave a mean on 55 sera of $9.85 \mathrm{mg}$. $/ 100 \mathrm{ml}$. \pm 1.26 (S.D.) and that of the calcon/E.D.T.A. method $9.70 \mathrm{mg} . / 100 \mathrm{ml} . \pm 1.24$ (S.D.). This gave a mean difference of $+0.15 \mathrm{mg} . / 100 \mathrm{ml} . \pm 0.029$

TABLE III

EFFECT OF ADDED PHOSPHATE ON CALCIUM ESTIMATION

\begin{tabular}{|c|c|c|c|}
\hline & $\begin{array}{l}\text { Total Phosphate Present } \\
(\mathrm{mg} . P / 100 \mathrm{ml} .)\end{array}$ & $\begin{array}{l}\text { Calcium Found } \\
(\mathrm{mg} . / 100 \mathrm{ml} .)\end{array}$ & Effect on End-point \\
\hline Serum I & $\begin{array}{r}3 \cdot 7 \\
5 \cdot 7 \\
8 \cdot 7 \\
13 \cdot 7 \\
18 \cdot 7 \\
23 \cdot 7 \\
53 \cdot 7\end{array}$ & $\begin{array}{c}9.4 \\
9.4 \\
9.4 \\
9.2 \\
9.0 \\
\text { No accurate result } \\
\text { No accurate result }\end{array}$ & $\begin{array}{l}\text { No interference } \\
\text { No interference } \\
\text { No interference } \\
\text { Moderate interference } \\
\text { Definite interference } \\
\text { Gross interference } \\
\text { Gross interference }\end{array}$ \\
\hline Serum II & $\begin{array}{r}4 \cdot 2 \\
6 \cdot 2 \\
9 \cdot 2 \\
12 \cdot 2 \\
14 \cdot 2 \\
19 \cdot 2 \\
24 \cdot 2\end{array}$ & $\begin{array}{c}\mathbf{9 \cdot 2} \\
\mathbf{9 \cdot 2} \\
\mathbf{9 \cdot 2} \\
\mathbf{9 \cdot 2} \\
\mathbf{9 \cdot 2} \\
\mathbf{9 \cdot 0} \\
\text { No accurate result }\end{array}$ & $\begin{array}{l}\text { No interference } \\
\text { No interference } \\
\text { Slight interference } \\
\text { Moderate interference } \\
\text { Definite interference } \\
\text { Gross interference } \\
\text { Gross interference }\end{array}$ \\
\hline Standard calcium solution & $\begin{array}{r}0 \\
3 \cdot 0 \\
5 \cdot 0 \\
11 \cdot 0 \\
20 \cdot 0 \\
50 \cdot 0 \\
100 \cdot 0\end{array}$ & $\begin{array}{c}10.0 \\
10.0 \\
10.0 \\
\text { No accurate result } \\
\text { No accurate result } \\
\text { No accurate result } \\
\text { No accurate result }\end{array}$ & $\begin{array}{l}\text { No interference } \\
\text { Very slight interference } \\
\text { Gross interference } \\
\text { Gross interference } \\
\text { Gross interference } \\
\text { Gross interference }\end{array}$ \\
\hline
\end{tabular}


(S.E.M.). The Student $t$ test gave $\mathrm{p}=<0.001$. Thus there is a small but significant difference between the mean values of the two series, indicating that the E.D.T.A. results are slightly lower than those obtained with the oxalate precipitation method. However, the difference does not appear to be as great as that reported for other E.D.T.A. titrations by Wilkinson (1957) and Golby et al. (1957).

CALCIUM ESTIMATIONS ON BIOLOGICAL SPECIMENS USING MORPHOLINE NITRATE-NITRIC ACID EXTRACTS

Horner (1955) and later Baron and Bell (1959) described a quick method for preparing protein and phosphate-free extracts from biological samples without the preliminary ashing or precipitation of calcium. Phosphates and proteins are directly precipitated with a morpholine nitrate-nitric acid reagent and sodium tungstate leaving a clear acid supernatant which, by the addition of the normal quantity of $\mathrm{NaOH}$, is ready for immediate titration with calcon and E.D.T.A.

REAGENTS FOR PRECIPITATION Two are required:-

1 Morpholine nitrate-nitric acid reagent (Horner, 1955; Baron and Bell, 1959) A 1:1 mixture of $25 \% \mathrm{v} / \mathrm{v} \mathrm{HNO}_{3}$ and $48 \%$ morpholine nitrate. $48 \%$ morpholine nitrate is made by adding $50 \% \mathrm{HNO}_{3}$ to $28 \mathrm{ml}$. morpholine until the solution is neutral followed by dilution with water to $100 \mathrm{ml}$. We found that it was essential to add $50 \% \mathrm{HNO}_{3}$ very slowly to morpholine cooled below $0^{\circ} \mathrm{C}$. If the temperature is allowed to rise above $5^{\circ} \mathrm{C}$. the resultant reagent may result in discoloration of the calcon giving poor end-points and high blank values.

2 Sodium tungstate $66 \% \mathrm{w} / \mathrm{v} \quad \mathrm{Na}_{2} \quad \mathrm{WO}_{4} 2 \mathrm{H}_{2} \mathrm{O}$

MORPHOLINE NITRATE PRECIPITATION Two millilitres of the sample, prepared to contain approximately 20 mg. $\mathrm{Ca} / 100 \mathrm{ml}$., $1 \mathrm{ml}$. sodium tungstate, and $2 \mathrm{ml}$. morpholine nitrate-nitric acid reagent are mixed thoroughly, allowed to stand for one hour at room temperature, and centrifuged for 10 minutes at 3,000 r.p.m.

TItration Pipette $1 \mathrm{ml}$. supernatant, $0.5 \mathrm{ml} .2 \mathrm{~N} \mathrm{NaOH}$, and $0.2 \mathrm{ml}$. dilute calcon into a titration beaker and titrate as previously described.

mg.Ca/100 ml. prepared sample $=$ test - blank $\times 10$ $2 \cdot 5$

RESULTS WITH URINE Direct titrations are possible on urine $(0.5 \mathrm{ml}$. or $0.2 \mathrm{ml}$.) with low phosphate concentrations but may become rather difficult on urine with large concentrations of phosphate. The calcium content of 23 urines was therefore estimated by the morpholine nitrate method described and for comparison by preliminary oxalate precipitation of calcium followed by titrations with E.D.T.A. and calcon. With this method $1 \mathrm{ml}$. of $4 \%$ ammonium oxalate was added to $2 \mathrm{ml}$. of urine $(p \mathrm{H} \mathrm{5})$ and $2 \mathrm{ml}$.

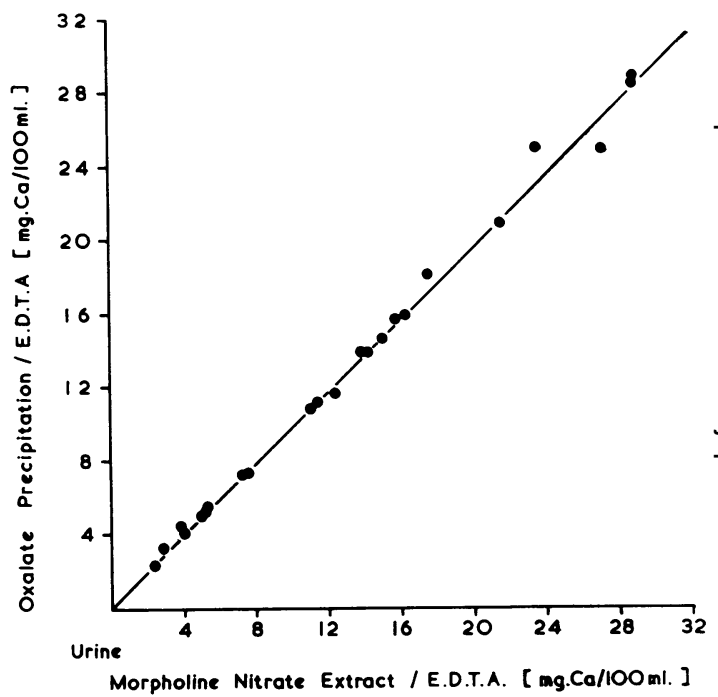

FIG. 2. Comparison of urine calcium estimations on 23 व samples.

Ordinate By oxalate precipitation followed by E.D.T.A. calcon titration.

Abscissa By morpholine nitrate precipitation followed by E.D.T.A./calcon titration.

of water. After mixing and leaving for one hour the precipitate was centrifuged for 10 minutes at $3,000 \frac{\mathrm{D}}{\mathrm{O}}$ r.p.m., the supernatant decanted off, and the precipitate dissolved in $0.5 \mathrm{ml} .2 \mathrm{~N} \mathrm{HCl}$ and made up to응 $4 \mathrm{ml}$. with water. One millilitre of solution $(=0.5 \mathrm{ml}$. urine) was titrated with E.D.T.A. and calcon. Figure $2 \frac{7}{0}$ gives the results obtained and shows good agreement between the two methods. The morpholine nitrate method is a slightly quicker and probably more 0 accurate method as it eliminates the need for the actual precipitation of calcium.

RESULTS WITH MILK AND FOOD The calcium content $\frac{\text { ? }}{9}$ of milk and food was estimated by the rather $>$ laborious method of ashing followed by titration of the calcium present with E.D.T.A. and calcon and by direct morpholine nitrate precipitation followed by titration of the supernatant produced with E.D.T.A. and calcon. The good agreement between $\mathrm{W}$ the two methods shown in Table IV indicates that the second rapid method is satisfactory.

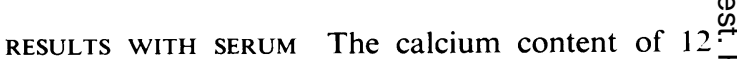
sera was estimated by direct titration with E.D.T.A. and calcon and by the morpholine nitrate method $\frac{\vec{\Phi}}{\mathrm{D}}$ described. Figure 4 shows that the results are closely $\frac{?}{\mathbb{Q}}$ comparable but it has been found unnecessary to use $\stackrel{\mathbb{Q}}{2}$ this longer method for routine work. However, in 
TABLE IV

ESTIMATION OF CALCIUM IN MILK AND FOOD BY TWO METHODS

\begin{tabular}{|c|c|c|c|}
\hline Sample & $\begin{array}{l}\text { Estimation after } \\
\text { Morpholine Nitrate } \\
\text { Precipitations }(a)\end{array}$ & $\begin{array}{l}\text { Estimation after } \\
\text { Ashing } \\
\text { (b) }\end{array}$ & $\begin{array}{l}\text { Difference } \\
\text { between }(a) \\
\text { and }(b)\end{array}$ \\
\hline \multicolumn{4}{|c|}{ Milk (mg./100 ml.) } \\
\hline I & $\begin{array}{l}120 \\
120\end{array}$ & $\begin{array}{l}127 \\
125\end{array}$ & -6 \\
\hline II & $\begin{array}{l}128 \\
133\end{array}$ & $\begin{array}{l}112 \\
112\end{array}$ & +18 \\
\hline \multicolumn{4}{|c|}{ Food ( $\mathrm{mg}$. of total diet) } \\
\hline I & $\begin{array}{l}660 \\
660\end{array}$ & $\begin{array}{l}635 \\
652\end{array}$ & +16 \\
\hline II & $\begin{array}{l}700 \\
742\end{array}$ & $\begin{array}{l}720 \\
720\end{array}$ & +1 \\
\hline III & 375 & 395 & -20 \\
\hline
\end{tabular}

cases with grossly raised phosphate levels the endpoints obtained are improved.

\section{ESTIMATIONS OF TOTAL MAGNESIUM AND CALCIUM IN} SERUM

Using the apparatus described the magnesium content of serum may also be estimated by first titrating the total calcium and magnesium present with E.D.T.A. at a $p \mathrm{H}$ of approximately 10.5 with Eriochrome black $\mathrm{T}$ indicator followed by titration of calcium only at a $p \mathrm{H}$ of approximately 13 with

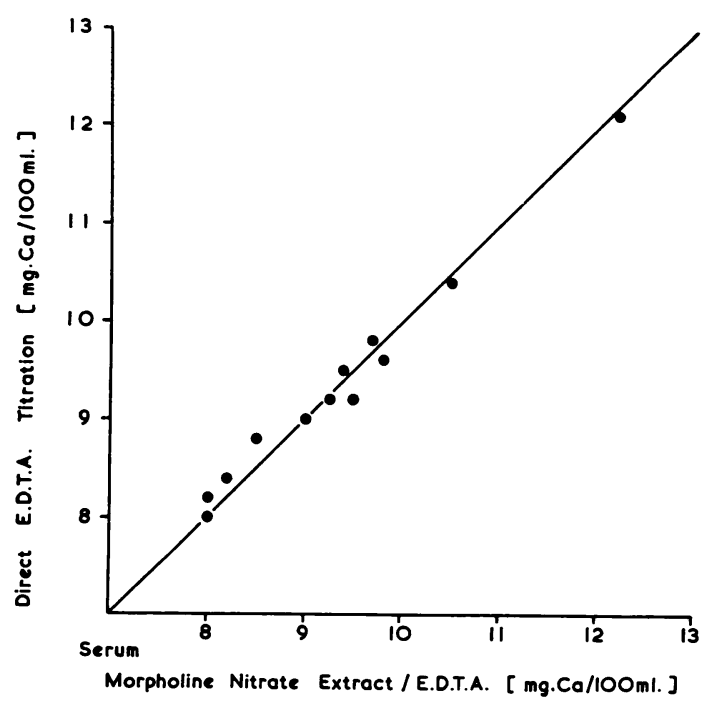

FIG. 3. Comparison of serum calcium estimations on 12 samples by direct E.D.T.A./calcon titration (ordinate) and after morpholine nitrate precipitation (abscissa).
E.D.T.A. and calcon as previously described. For each titration $0.5 \mathrm{ml}$. of serum is required.

The reagents used for total magnesium and calcium estimations are basically the same as described by Wilkinson (1957) but adjusted to suit the smaller volumes required for the apparatus by using $1 \mathrm{ml}$. of Eriochrome dye buffer solution which had the dye concentration reduced by $40 \%$.

REAGENTS These are as follows:-

Stock magnesium standard $(50 \mathrm{mg} . / 100 \mathrm{ml}$. $\mathrm{Mg} \cdot \mathrm{SO}_{4} \cdot 7 \mathrm{H}_{2} \mathrm{O}, 2.5328 \mathrm{~g}$., is dissolved in $500 \mathrm{ml}$. ion exchange distilled water.

Dilute magnesium standard $(5 \mathrm{mg} . / 100 \mathrm{ml}$.) Dilute stock solution 1:10 with distilled water.

Ethanolamine ( 2 hydroxethanolamine, B.P. $173^{\circ} \mathrm{C}$.) It may be necessary to re-distil this reagent.

Methyl alcohol absolute $A R$

Eriochrome black $T$ stock dye solution Dissolve $400 \mathrm{mg}$. Eriochrome black T (G. T. Gurr Ltd.) in $100 \mathrm{ml}$. methyl alcohol, add $4 \mathrm{ml}$. ammonia AR 0.88 SG solution, and store in a polythene bottle. The dye is stable up to five or six months.

Dye buffer solution Eriochrome dye, $0.5 \mathrm{ml}$,, and $0.5 \mathrm{ml}$. ethanolamine are made up to $50 \mathrm{ml}$. with distilled water. The dye buffer solution is made freshly each day.

METHOD The use of the apparatus is the same as described for the estimation of calcon. The Eriochrome black $\mathrm{T}$ colour change is sharper than that of calcon and the change of optical density is greater, so that the sensitivity settings of the galvanometer must be lowered.

CHECK ON E.D.T.A. STANDARDIZATION Into the titration beaker pipette $1 \mathrm{ml}$. or $1.2 \mathrm{ml}$. magnesium dilute standard and add $2 \mathrm{ml}$. of dye buffer solution. Titrate with E.D.T.A. until the full colour change has been observed and the E.D.T.A. titration figure giving the greatest galvanometer deflection noted.

$1 \mathrm{ml}$. magnesium standard $=0.833 \mathrm{ml}$. E.D.T.A.

$1.2 \mathrm{ml}$. magnesium standard $=1 \mathrm{ml}$. E.D.T.A.

It is useful to cross check the E.D.T.A. solution both with the magnesium standard and Eriochrome black $T$ and with the calcium standard and calcon. After allowing for blank values there should be complete agreement of standardization.

TITRATION OF TOTAL CALCIUM AND MAGNESIUM IN SERUM Into the titration beaker pipette $0.5 \mathrm{ml}$. serum, add $1 \mathrm{ml}$. dye buffer solution, and titrate as before. Maximum accuracy is obtained using 0.01 additions of E.D.T.A. The $p \mathrm{H}$ of the dye buffer and serum is approximately $10 \cdot 5$.

Calcium only is estimated on a further $0.5 \mathrm{ml}$. of serum as described previously.

CALCULATION The titration for magnesium equals the total calcium and magnesium titre minus the titre for calcium only. $[\mathrm{Mg}(\mathrm{mg} . / 100 \mathrm{ml}$.) $=$ titre $\mathrm{Mg} \times 2 \times 5 /$ standard reading $(1 \mathrm{ml}$.$) .]$

RECOVERY OF MAGNESIUM ADDED TO SERUM Varying quantities of magnesium sulphate solution (as $50 \mathrm{mg}$. 
TABLE V

RECOVERY OF MAGNESIUM ADDED TO A NORMAL SERUM

\begin{tabular}{lllr}
$\begin{array}{l}\text { Magnesium } \\
\begin{array}{l}\text { Added } \\
(\mathrm{mg} . / 100 \mathrm{ml} .)\end{array}\end{array}$ & $\begin{array}{l}\text { Magnesium } \\
\text { Found } \\
(\mathrm{mg} . / 100 \mathrm{ml} .)\end{array}$ & $\begin{array}{l}\text { Magnesium } \\
\text { Recovered } \\
(\mathrm{mg} . / 100 \mathrm{ml} .)\end{array}$ & $\begin{array}{l}\% \\
\text { Recovery }\end{array}$ \\
\hline & 2.75 & - & - \\
1.0 & 3.76 & 1.01 & 101.0 \\
2.0 & 4.70 & 1.95 & 97.5 \\
5.0 & 7.78 & 5.03 & 100.3 \\
10.0 & 12.60 & 9.85 & 98.5 \\
20.0 & 22.60 & 19.85 & 99.4
\end{tabular}

$\mathrm{Mg} / 100 \mathrm{ml}$.) were added to a serum of known calcium content and after titration the recoveries were calculated.
Table $\mathrm{V}$ shows that the method gives satisfactory recoveries up to $20 \mathrm{mg}$. $\mathrm{Mg} / 100 \mathrm{ml}$.

We wish to thank Professor N. F. Maclagan for his $\stackrel{\overrightarrow{\vec{P}}}{\overrightarrow{\mathrm{C}}}$ interest and help while these experiments were in progress.

\section{REFERENCES}

Baron, D. N., and Bell, J. L. (1959). J. clin. Path., 12, 143. Bett, I. M., and Fraser, G. P. (1959). Clin chem. Acta, 4, 346. Clark, E. P., and Collip, J. B. (1925). J. biol. Chem., 63, 461.

Golby, R. L., Hildebrand, G. P., and Reilley, C. N. (1957). J. Lab. clin. Med., 50, 498.

Hildebrand, G. P., and Reilley, C. N. (1957). Analyt. Chem. 29258

Horner, W. H. (1955). J. Lab. clin. Med., 45, 951.

Wheatley, V. R. (1944). Analyst, 69, 207.

Wilkinson, R. H. (1957). J. clin. Path., 10, 126.

\section{The November 1962 Issue}

\section{THE NOVEMBER 1962 ISSUE CONTAINS THE FOLLOWING PAPERS}

Haemagglutination in acute hepatitis and other diseases PAUL TURNER, V. N. JHA, NUALA CROWLEY, and SHEILA SHERLOCK

An epidemiological study of haemagglutination in hepatitis JAMES R. MCARTHUR and NUALA CROWLEY

Blood clotting factors in cerebrospinal fluid STEFAN NIEWIAROWSKI, IRENA HAUSMANOWA-PETRUSEWICZ, and ZENON WEGRZYNOWICZ

Observations on the separate assessment of ProwerStuart factor activities C. GARDIKAS, C. LYBERATOS, G. KALLINIKOS, and M. KALLINIKOU

An investigation into the use of activated and nonactivated papain in routine rhesus blood grouping G. C. B. WINTER and B. E. WRATTEN

The contact phase of coagulation in the presence of heparin A. L. BLOOM

Muscle morphology in infantile protein malnutrition R. D. MONTGOMERY

The diagnosis of the scars of chronic pyelonephritis J. F. SMITH

Laryngeal dysfunction and the pulmonary syndrome of the newborn G. R. OSBORN and R. L. FLETT

Haematoxylin bodies in Hodgkin's disease $\mathrm{N}$. CANDREVIOTIS

Resistance of Salmonella typhi to chloramphenicol B. RAMANARAYANA MURTI, K. RAJYAlaKSHMI, and c. S. BHASKARAN

Part I A preliminary report

Part II The mechanism of resistance The dispersal of staphylococci in hospital wards w. C. $\vec{\oplus}$
NOBLE

The dispersal of organisms from minor septic lesions B. T. THOM and R. G. WHITE

Serum tube identification of Candida albicans

D. W. R. MACKENZIE

A simple colorimetric method for the determination of $\mathbb{D}$ serum alpha-hydroxybutyric dehydrogenase activity S. B. ROSALKI

The incidence of cryoglobulinaemia as determined by a turbidimetric method L. BAGRATUNI

The determination of urinary 17 -ketosteroids by an improved Zimmermann reaction R. N. BEALE, J. O.? BOSTROM, and D. CROFT

Blood pyruvate concentration measured by a specific method in control subjects J. LANDON, J. K. FAWCETT, O and VICTOR WYNN

The estimation of two alpha ${ }_{1}$ glycoproteins (orosomucoid 음 and another alpha $a_{1}$ acid glycoprotein) in health and $D$ disease J. A. EASTON, J. HARDWICKE, and P. H. WHITEHEAD

\section{Technical methods}

An improved container for cells preserved by freezing J. H. L. PLAYFAIR and D. E. PEGG

Macroscopic demonstration of infarction in fresh brain slices D. N. RAINE

A routine immunofluorescence method for detecting autoantibodies to thyroid colloid R. C. NAIRN, T. GHOSE, $\mathbb{D}$ I. B. PORTEOUS, and J. A. URQUHART

Book reviews

Index to volume 15

Copies are still available and may be obtained from the PUBLISHING MANAGER, BRITISH MEDICAL ASSOCIATION, TAVISTOCK SQUARE, W.C.I, price 17s. 6D. 